\title{
ASSOCIATION OF DIABETES MELLITUS AND SMOKING WITH ISCHAEMIC STROKE
}

\begin{abstract}
KIRTANIA $\mathrm{K}^{1}$, SULTANA N²${ }^{2}$, HOSSAIN MZ³ ${ }^{3}$ AHMED ${ }^{4}$, KHATUN A ${ }^{5}$
Abstract

Diabetes mellitus is one of the most important modifiable risk factors for ischemic stroke. Cigarette smoking is a risk factor for atherosclerotic disease. There is a strong relationship between diabetes mellitus and cigarette smoking with ischemic stroke. A case control study was designed to see the association of diabetes mellitus and cigarette smoking with ischaemic stroke. The study was done from January 2009 to December 2009. Sixty subjects were selected as study population which were taken from Dhaka medical college hospital, Dhaka. Among them 30 were diagnosed case of ischemic stroke and 30 were age and sex matched control. The study showed that 33.33\% patients of case group and $10 \%$ respondents of control group had diabetes mellitus. It also revealed that $56.66 \%$ of case group and 53.33\% of control group were smoker and the mean duration of smoking was $27.41 \pm 2.98$ years in case group and $15.63 \pm 2.85$ years in control group. The study suggests that diabetes mellitus is significantly associated with ischemic stroke and longer duration of smoking is also associated with ischaemic stroke.
\end{abstract}

Key words: Ischemic stroke, cigarette smoking, diabetes mellitus.

J Dhaka Med Coll. 2011; 20(1) : 12-14.

\section{Introduction:}

After coronary artery disease and cancer, stroke is the third commonest cause of death in the developed countries ${ }^{1}$. It predominates in the middle and late years of life. Traditional risk factors for stroke include advanced age, hypertension, diabetes mellitus, heart disease, elevated serum cholesterol, obesity, cigarette smoking, lower socioeconomic class and drug use and abuse $\mathrm{e}^{2,3}$. Diabetes mellitus is an important risk factor for stroke. Several studies have indicated that even mild hyperglycemia in the acute infarction period is associated with poor outcome ${ }^{4}$. Cigarette smoking increases the risk of ischemic stroke nearly two times; with a clear dose-response relation. Risk of ischemic stroke is more in the current smoker than the ex-smoker. The mechanism by which smoking is thought to increase the likelihood of ischemic stroke include increased fibrinogen level and platelet adhesiveness and reduced cerebral blood flow mainly due to atheroma formation and higher blood viscosity in chronic smoker 5 . The present study was carried out to see the association of diabetes mellitus and smoking with the ischemic stroke.

\section{Materials and Methods:}

The study was carried out in the Department of Biochemistry, Dhaka Medical College, Dhaka, during the period of January to December 2009. The patients were taken from the Department of Neurology and Medicine unit of Dhaka Medical College Hospital (DMCH). Ischaemic stroke patients were considered as case and the control were age and sex matched volunteers .Cases were the patients who clinically suffered from ischemic stroke

1. Dr. Kalyan Kirtania, Assistant Professor, Department of Biochemistry, Jahurul Islam Medical College, Bazitpur, Keshoregonj.

2. Dr. Nasima Sultana, Associate Professor, Department of Biochemistry, Dhaka Medical College, Dhaka.

3. Mohammad Zaid Hossain, Assistant Professor, Dept. of Medicine, Dhaka Medical College, Dhaka.

4. Prof. Selina Ahmed, Professor \& Head, Department of Biochemistry, Dhaka Medical College, Dhaka.

5. Dr. Asma Khatun, Medical Officer, Institute of Epidemiology, Disease Control and Research (IEDCR), Mohakhali, Dhaka.

Correspondence: Dr. Kalyan Kirtania, Assistant Professor, Department of Biochemistry, Jahurul Islam Medical College, Bazitpur, Keshoregonj, Email:drkirtaniagb@yahoo.com 
confirmed by computerized tomography (CT) scan of brain attending the Neurology and Medicine units of $\mathrm{DMCH}$ during the study period. In this study, sample size were taken as 60.Thirty patients with ischaemic stroke were taken as cases among which 21 were male and 9 were female and 30 healthy volunteers were taken as controls among which 21 were male and 9 were female. Data were analyzed by computer with the help of SPSS version 12.0. All data were recorded systematically in a preformed data collection sheet. Categorical variables were analyzed by using the chi-square test. For all the statistical analysis 2-tailed 'p' values $<0.05$ were considered as significant.

\section{Results:}

In this study $33.33 \%$ patients of case group and $10 \%$ respondents of control group had diabetes mellitus. Statistical analysis showed significant difference between the two groups in term of presence of diabetes mellitus ( $p$ $=0.028)$ (Table-I). Again the study showed that $17(56.66 \%)$ patients of case group and 16 (53.33\%) respondents of control group were smoker. No statistically significant difference was observed between case and control groups regarding the habit of smoking ( $\mathrm{p}$ value $>0.50$ ) (Table-II). The mean duration of smoking was $27.41 \pm 2.98$ years in case group and $15.63 \pm 2.85$ years in control group. There was difference between the two groups regarding the duration of smoking which was statistically highly significant $(p=0.0001) \quad$ (Table-III). Longer duration of smoking was associated with ischaemic stroke.

Table -I

Association of diabetes with case and control groups

\begin{tabular}{lccccc}
\hline $\begin{array}{l}\text { Study } \\
\text { group }\end{array}$ & $\begin{array}{c}\text { Number of } \\
\text { Diabetic } \\
\text { Subjects }\end{array}$ & $\begin{array}{c}\text { Number of } \\
\text { Non- Diabetic } \\
\text { subjects }\end{array}$ & Total & $\begin{array}{c}\chi 2 \\
\text { Value }\end{array}$ & $\begin{array}{c}p \\
\text { value }\end{array}$ \\
\hline Case & $10(33.33)^{*}$ & $20(66.67)$ & $30(100)$ & 8.297 & 0.004 \\
Control & $03(10)$ & $27(90)$ & $30(100)$ & & \\
\hline Total & $13(21.67))$ & $47(78.33)$ & $60(100)$ & & \\
\hline
\end{tabular}

* Figures in the parentheses denote corresponding \%

Table-II

Comparison of smoking habit between case and control groups.

\begin{tabular}{lccccc}
\hline $\begin{array}{l}\text { Study } \\
\text { group }\end{array}$ & $\begin{array}{c}\text { Number of } \\
\text { Smoker }\end{array}$ & $\begin{array}{c}\text { Number of } \\
\text { non Smoker }\end{array}$ & Total & $\begin{array}{c}\chi 2 \\
\text { Value }\end{array}$ & $\begin{array}{c}\mathrm{p} \\
\text { Value }\end{array}$ \\
\hline Case & $17(56.66) *$ & $13(43.34)$ & $30(100)$ & 0.067 & 0.795 \\
Control & $16(53.33)$ & $14(46.67)$ & $30(100)$ & & \\
Total & $33(55.00)$ & $27(45.00)$ & $60(100)$ & & \\
\hline
\end{tabular}

* Figures in the parentheses denote corresponding \%

Table-III

Comparison of smoking duration between case and control

\begin{tabular}{lccc}
\hline Group & Mean duration of & $\mathrm{t}$ value & $\mathrm{p}$ value \\
& Smoking in years & & \\
\hline Case $(\mathrm{n}=17)$ & $27.41 \pm 2.98^{*}$ & 11.599 & 0.0001 \\
Control $(\mathrm{n}=16)$ & $15.63 \pm 2.85$ & & \\
\hline
\end{tabular}

* Unpaired ' $\mathrm{t}$ ' test was done to test significance; level of significance was 0.05. 


\section{Discussion:}

Diabetes mellitus is an important risk factor for stroke. Uncontrolled diabetes causes premature atherosclerosis resulting cerebral thrombosis and ischemic stroke. Diabetes also causes endothelial proliferation and thickening of the basement membrane in the small blood vessels. Type 2 diabetes mellitus in the elderly is associated with increased incidence of vascular disease, particularly, atherosclerosis of large blood vessels (Messier et al. 2004). In this study $33.33 \%$ patients of case group and $10 \%$ respondents of control group had diabetes mellitus. Statistical analysis showed significant difference between the two groups in term of presence of diabetes mellitus $(p=0.028)$. Khan $(2000)^{7}$, in his hospital based case control study in Bangladesh, found that diabetes mellitus is a strong risk factor for stroke. The study revealed that $33 \%$ of cases and $13 \%$ of controls were diabetic. In the present study, showed that $56.66 \%$ of case group and $53.33 \%$ respondents of control group were smoker. No statistically significant difference was observed between case and control groups regarding the habit of smoking ( $\mathrm{p}$ value $>0.50$ ). But there was difference between the two groups regarding the duration of smoking. The mean duration of smoking was $27.41 \pm 2.98$ years in case group and $15.63 \pm 2.85$ years in control group which is statistically highly significant $(\mathrm{p}=0.0001)$. Longer duration of smoking was associated with ischaemic stroke. Sacco et al. $(1997)^{5}$ in their study found cigarette smoking increases the relative risk (RR) of ischemic stroke nearly two times; with a clear doseresponse relation. In USA, Rohr et al. (1996) ${ }^{8}$ found that longer duration of cigarette smoking had the population attributable risk percent (95\% CI intervals) for stroke among the white men was $22.6 \%$ and in the black men was $40.5 \%$.

\section{Conclusion:}

Analytical results of this study reveals that the patients of ischemic stroke have been found to have close association with Diabetes mellitus and cigarette smoking. This study suggest that diabetic patients need measurement of blood sugar at regular interval to prevent ischemic stroke by controlling blood sugar and give up of smoking habit.

\section{References:}

1. Adams RD, Victor M, Roper JH. Principles of neurology. $6^{\text {th }}$ ed. New York: McGraw-Hill; 1997. p. $170-6$.

2. Fang, XH, Kronmal RA, Li SC, Longstreth WT Jr, Cheng XM, Wang, WZ. Prevention of stroke in urban China: a community based intervention trial. Stroke 1999; 30(3): 495-501.

3. Danesi MA, Oneyola YA, Onitiri AC. Risk factors associated with cerebrovascular disease in Nigerian: a case control study. E Afr Med J 1983; 60(3): 190-5.

4. Matcher DB, Divine GW, Heyman A, Feussner JR. The influence of hyperglycemia on outcome of cerebral infarction. Ann Intern Med 1992; 117: 449-56.

5. Sacco RL, Benjamin EJ, Broderick JP, Mark D, Easton JD, Feinberg WM. Risk factors. Stroke 1997; 28: 1507-17.

6. Messier C, Awad N, Gayvaon M. The relationships between atherosclerosis, heart diseases, type 2 diabetes and dementia. Neurol Res 2004; 25: 56772 .

7. Khan MRK. Relationship between blood lipids, lipoproteins and ischaemic stroke [MPhil Thesis]. BSMMU, Dhaka. 2000.

8. Rohr J, Kittner S, Feeser B, Hebel JR, Whyte MG, Weinstein $\mathrm{A}$, et al. Traditional risk factors and ischemic stroke in young adults: the BaltimoreWashington Cooperative Young stroke Study. Arch Neurol 1996; 53(7): 603-7. 